\title{
Water Management Is Key in Reducing Nutrient Runoff from Container Nurseries
}

Ted E. Bilderback

Additional INDEX wORDs. irrigation efficiency, cycled irrigation, riparian buffers, grassed waterways

Summary. Environmentally compatible production practices are conscious efforts to design and retrofit nursery container growing areas to improve irrigation and nutrient efficiency, and reduce exposure of ground and surface water supplies to contaminated effluent. Irrigation of ornamental crops in containers can be very inefficient, using large quantities of water and fertilizer. Irrigation water and fertilizer use efficiencies are directly related to each other. Improving irrigation efficiency improves nutrient efficiency and reduces water volume and nutrients leaving production beds.

Increasing efficiency can be accomplished in many ways. Grouping plant species and container sizes into blocks with similar water requirements improves efficiency. Redesigning overhead sprinkler systems to accomplish uniform distribution across growing beds or replacing worn nozzle orifices can significantly reduce application variability. Low volume/low pressure systems that distribute water directly into containers and apply less water in a specific amount of time compared to overhead sprinkler application, will conserve water. Applying irrigation in short cycles rather than long cycles improves wetting in substrates and conserves electrical energy, water and directly reduces nutrient leaching from containers. Creating microclimates in nurseries to optimize light or reduce container temperatures, disease pressure and crop stress can improve water and nutrient efficacy. Flow of water running off growing areas must be engineered to slow velocity, filter and contain effluent. Strategies should be site-specific. Capture, containment and recycling of irrigation water has been a common practice in many nurseries in the U.S., as a means to provide adequate water supplies. Vegetative filter strips adjacent to beds and containment basins have been installed at nurseries to reduce contaminants in runoff before water enters recycle irrigation supplies. In areas with sandy soils, some nurseries have developed closed systems where drainage channels and collection basins are lined to prevent nitrogen movement from runoff into shallow groundwater.

rowing plants in containers is a unique production system
compared to growing plants in soil. For most agronomic
crops, annual fertilizer application rates are based on expected (realistic) yield and soil characteristics, which in turn dictate reasonable fertilizer application rates used to produce various crops. Such nutrient management strategies are not possible for container plant production since the amount of fertilizer applied per unit area is dependent on container population density (spacing), container size, ornamental species produced, method of fertilizer application (soluble liquid feed, incorporation of controlled release fertilizer, or surface application of controlled release fertilizers), season of growth and number of crops produced yearly in an area. In addition, nutrient absorption occurs only when nutrients are soluble in solution in containers and are highly subject to leaching during irrigation. Therefore, methods directed to reducing environmental impacts for ornamental container crops are irrigation and runoff management strategies. 
Bestmanagementpractices (BMPs) are practices that prevent or reduce discharges of pollutants (Yeageretal., 1997). The BMP philosophy emphasizes environmental stewardship withoutsacrificing crop quality. BMPs include schedules of activities, maintenance procedures, grading, vegetation, structural land modification, and other management practices found to be effective and practical in preventing or reducing the discharge of pollutants. BMPs can conserve and protect water resources fromadverse environmental impacts that might result from cultural practices used toproduce plants. BMPsare site-specific and menu-driven, thus not all will be implemented, but as many as possible should be incorporated into the production system. BMPs provide uniform production guidelines regardless of nursery or greenhouse acreage, or location.

\section{Improving overhead sprinkler irrigation efficiency by design and cycling irrigation}

Most nursery crops grown in containers up to $5 \mathrm{gal}$ (18.9 L) are irrigated by overhead sprinkler irrigation. This type of irrigation system is often very inefficient. Poorly designed overhead irrigation systems can have as much as $300 \%$ variability in the amount of water applied within an irrigation zone (Fare et al., 1994). Most growers use overhead irrigation sprinklers to irrigate small container plants because they do not consider individual irrigation emitters on small containers to be economically feasible. The design of the irrigation system has the greatest influence on the efficiency of the overhead system, second only to environmental influences such as wind (Furuta, 1978). Several configurations of design and layout of risers for overhead systems are possible, including square, triangular, and rectangular patterns with sprinklers rotating $360^{\circ}$ or in partial circles. The most efficient overhead irrigation system for many nurseries may be a square irrigation design with $90^{\circ}$ spray patterns for corner nozzles and $180^{\circ}$ patterns for middle nozzles, where water is distributed from irrigation nozzle to irrigation nozzle. Distance between risers is determined by the pump, main line, distribution lines, compatible volumes and pressures for nozzle sizes selected, and environmental conditions such as wind. However, risers are frequently spaced 36 to $40 \mathrm{ft}$ (11 to $12 \mathrm{~m}$ ) apart in a square pattern.
Use of a single daily overhead irrigation cycle per zone of nursery container stock has been a standard practice (Fare et al., 1994). However, irrigation practices are being reexamined. Several studies have reported that cyclic irrigation where daily irrigation is applied in separate cycles rather than one irrigation application improves irrigation and nutrient efficiency (Groves etal., 1998a, 1998b; Lamackand Niemiera, 1993; Tyler et al., 1996a, 1996b). Groves et al. (1998b) found that irrigation efficiency for cyclic irrigation compared to a single irrigation varied depending on the amount of irrigation volume applied and crop grown. Irrigation efficiencies averaged over an entire growing season with daily applications of $6.8,13.5,27.1$, and $40.6 \mathrm{fl} \mathrm{oz}(200,400,800$, and $1200 \mathrm{~mL})$ for 'Skogholm' cotoneaster (Cotoneaster dammeri) were $95 \%, 84 \%, 62 \%$, and $48 \%$ while 'Goldstrum' coneflower (Rudbeckia fulgida) was $100 \%, 90 \%, 72 \%$, and $51 \%$, respectively. Nutrient concentrations in container solution decreased with increasing irrigation volume with all of the three controlled releasefertilizerproductstested. Groves etal.(1998a) further reported that 90\% ofmaximum growth could beachieved with $40 \%$ reduction of irrigation applied. Fare et al. (1994) reported that leachate volumes were reduced $54 \%$ with overhead cyclic irrigation compared to one overhead irrigation interval. Fare also found that $63 \%$ of $0.21 \mathrm{oz}(6.0 \mathrm{~g})$ of nitrogen $(\mathrm{N})$ appliedas Osmocote 17N-3.0P-10K(177-12; The Scotts Co., Marysville, Ohio) was lost as $\mathrm{NO}_{3}$ in the effluent during a growing season with a single irrigation application compared to $46 \%$ for cycled irrigation. Lamack and Niemiera (1993) reported that irrigation application efficiency with individual spray stakes applying irrigation to the substrate surface increased with increasing number of cycles. Tyler et al. (1996a) did not improve efficiency with 2, 3 , or 6 irrigation cycles using spray stakes but had $38 \%$ improvement in irrigation efficiency with cycled irrigation compared to a single application strategy. Tyler et al. (1996b) reported that when cyclic irrigation (volume of irrigation applied) was reduced by $44 \%$, the volume of effluent lost from containers decreased by $63 \%$. Nutrients leached are also directly related to irrigation application. With $44 \%$ less irrigation volume applied $\mathrm{NO}_{3}, \mathrm{NH}_{4}$, and $\mathrm{P}$ content in the effluent decreased by $66 \%, 62 \%$, and $57 \%$ respectively. The $44 \%$ reduction of water application resulted in $10 \%$ decrease in plant dry weight.

\section{Low-pressure irrigation systems are efficient for larger nursery containers}

Microirrigation (low pressure irrigation) systems can provide a very efficient means for applying water and nutrients to container or field grown nursery crops. These systems distribute water directly into containers and apply less water in a specific amount of time than overhead sprinklers, thereby conserving water. Low pressure irrigation systems use drip emittersorspray-staketypesofirrigationnozzles. The emitters often require only 15 to 30 $\mathrm{lb} /$ inch $^{2}$ (103.5 to $207.0 \mathrm{kPa}$ ) and, depending on the emittersselected, apply 0.5 to $15 \mathrm{gal} / \mathrm{h}\left(1.9\right.$ to $\left.56.8 \mathrm{~L} \cdot \mathrm{h}^{-1}\right)$ of water. Where long distribution lines are required or when the field has uneven terrain, pressure compensated emitters can be purchased to provide even distribution of water. Emitter and spray-stake orifices are much smaller than overhead sprinkler nozzle orifices and can become clogged. Sediment is much less of a problem when the supply is clean well water, municipal water, or water that is adequately filtered. However, even clean water may require a screen filter [200 to 100 mesh (80 to 152 $\mu \mathrm{m})]$ to ensure that small particle impurities will not plug orifices. Most water supplies from surface water, such as ponds, will need to be filtered if it is to be used for microirrigation emitters. Sand media filtration systemsare usually required for drip systems using surface water, howeverspray stakes may only require screen or disk filters. Water treatment may be needed for irrigation water that has iron concentrations as low as $0.5 \mathrm{ppm}\left(\mathrm{mg} \cdot \mathrm{L}^{-1}\right)$ or bicarbonate levels of $100 \mathrm{ppm}$ to avoid clogging of emitters over time. Most commercial water, plant, and soil testing labs provide analytical services for irrigation water supplies. Somelabsinclude recommended rates for various acidification techniques when bicarbonates are high enough to be a problem. No matter how good the filtration and maintenance, scouting irrigation lines and emitters must be done frequently to avoid problems with tubes pulled out of pots and for clogging.

\section{More ideas for improving irrigation efficiency}

Plants should be grouped by container size, substrate type and plant water needs. Grouping plants by species that have similar water needs frequently will improve growth of crops as well as conserve water. A table with many ornamental cropslisted bywater requirement isprinted 
in the Best Management Practices Guide for Producing Container Grown Plants (Yeager et al., 1997). Plants that require large amounts of waterand fertilizershould be located at the farthest point in the production area from any body of water, whether a stream or drainage channel to decrease the risk of polluting adjacent or nearby by water bodies.

Irrigation shutoff devices can be installed for irrigation systems to minimize nutrient runoff. Rain override sensors can be installed on irrigation controllers to skip irrigation cycles if significant amounts of rainfall have occurred within the past few hours. When beds are unoccupied after containers have been shipped, cutoffvalves on individual risers conserve water supplies and reduce runoff volumes.

\section{Analysis of irrigation water, leachates and tissue help develop a nutritional program}

Growers should monitor electrical conductivity (EC) and $\mathrm{pH}$ in irrigation supplies during the growing season. Moderate concentrations of ECs during summer months might be assumed to be indicators of nitrogen or other essential nutrient content. In fact under drought conditions sulfates and chlorides become concentrated in water supplies rather than essential nutrients and only laboratory analysis can confirm what management strategies need to be used.

Thesoillesspottingsubstratesinwhich container plants are grown are considered deficient in nutrient content without supplemental fertilization. These substrates contain primarily organic and inert components such as pine bark, sphagnum peat moss, sand or perlite. Composts from crop residues, yard, animal, or kitchen wastes may contain some nutrients and require analysis. Nutrients essential forplant growth are routinelyincorporated, surface applied, or supplied in irrigation to soilless potting substrates.

When fertilizer is injected in the overhead irrigation system, best management practices strongly recommend total capture of irrigation runoff with no runoff leaving nursery property. Much of the irrigation water falls between containers, so large quantities of runoff water contain nutrient levels sufficient for growing crops. Conversely, low pressure irrigation systems can be efficiently used for direct injection of fertilizers with the irrigation water. Nutrients are applied directly to the root zone of plants with negligible poten- tial for environmental impact from runoff if irrigation is managed to produce minimal leaching.

Controlled release fertilizers (CRFs) are synthetically produced products with extended sustained release patterns ranging from several weeks to several months. Growers frequently choose between products with a longevity of 5 to 6 months, 8 to 9 months, and 11 to 12 months based on the crops need and how long the crop will remain at the nursery. Most controlled release fertilizers used to supply $\mathrm{N}, \mathrm{P}$, and Kto nursery crops are plastic, resin or sulfur encapsulated. These fertilizers are more efficient than water-soluble fertilizers, in that a greater percentage of applied nutrients are used by the plant. Conversely fewer nutrients leach from the root zone since only small nutrient amounts are released through the coating at any point in time. The technology is expensive. CRFs generally range in cost from $\$ 0.50$ to $\$ 1.00 / \mathrm{lb}(\$ 1.10$ to $\$ 2.20 / \mathrm{kg})$ of product that may be $\$ 3.00$ to $\$ 6.50 / 1 \mathrm{~b}$ of $\mathrm{N}$ $(\$ 6.61$ to $\$ 14.33 / \mathrm{kg})$. Therefore nurseries diligently employ practices that will maximize the efficiency of the CRF products. Controlled release fertilizers have labels that provide low, medium and high application rates based on university and growers research for particular container size, application method and plant growth characteristics. However, the amount of nitrogen applied generally determines the rate used. Best Management guidelines indicate that adequate growth of most container ornamentals can be produced with about $0.12 \mathrm{oz}$ of $\mathrm{N} / \mathrm{l}$-gal container $\left(0.9 \mathrm{~g} \cdot \mathrm{L}^{-1}\right)$. Crops are listed by the rate of fertility preference for production in the BMP manual (Yeager et al., 1997).

Studies have been conducted to determine whether incorporating or surface application ofCRFs produces larger plants (Eakes et al., 1990; Yeager et al., 1989; Warren et al., 1997). Substrates should be amended with CRFs rather than surface applying fertilizer if containers are frequently subject to blow over (Yeager et al., 1997). Warren et al. (1997) compared surface application and incorporation of two CRFs for leachate nutrient losses. Results illustrated that method of fertilizer application does affect nutrient losses in irrigation effluent. Incorporating CRFs increased $\mathrm{NO}_{3}-\mathrm{N}$ and $\mathrm{P}$ losses in irrigation an average of $171 \%$ and $58 \%$, respectively.

Monitoring container leachates can help growers take preventive steps to reduce possible damage to roots due to high electrical conductivity before visible symptoms occur. Some nurseries monitor ECs weekly to determine how they will irrigate each irrigation zone the following week. If leachate ECs are elevated, more water will be applied the following week; if ECs are low, irrigation volume will be decreased in those zones the following week. The BMP manual recommends that growers monitor EC at least once a month. In the southeastern U.S. most growers and university faculty use the Virginia Tech Extraction Method(VTEM)(Wright, 1986). Nutrient concentrations, $\mathrm{pH}$ and electrical conductivity levelscan be monitored by pouring a $4.0 \mathrm{fl} \mathrm{oz}(120 \mathrm{~mL})$ of irrigation water per 1 -gal $(3.8-\mathrm{L})$ container over the surface of the medium about $30 \mathrm{~min}$ to 2 $\mathrm{h}$ after irrigation, and collecting the effluent that comes out of the bottom of the container. Actually growers can just collect solution that drips out of the container 30 min to $2 \mathrm{~h}$ after irrigating. Minimal levels for EC should range from 0.2 to 0.5 $\mathrm{dS} \cdot \mathrm{m}^{-1}$ for CRFs and 0.5 to $1.0 \mathrm{dS} \cdot \mathrm{m}^{-1}$ for liquid feed or combinations of CRFs and liquid. Maximum levels for most pine bark based substrates should not exceed 2.0 $\mathrm{d} S \cdot \mathrm{m}^{-1}$ (Yeager et al., 1997). To test the leachate solution, a grower needs to purchase a $\mathrm{pH}$ and conductivity meter. Prices range approximately $\$ 49$ or more; however, inexpensive glass electrode $\mathrm{pH}$ pens and conductivity pens when calibrated with appropriate standard solutions, do provide accurateresultsand cansave $\$ 1000$ s in nursery stocklosses. Sending the leachate solution for laboratory analysis at least once during the growing season is a good idea, so that actual nutrient levels in the container are known and corrected if needed. Leachate analysis and plant tissue analysis are the best diagnostic steps to determine nutritional disorders.

\section{Managing and capturing runoff in nurseries}

Capture, containment, and recycling of irrigation water has been implemented in many nurseries in the U.S. as a means to provide adequate water supplies. As environmental concern about runoff has increased in recent years, this practice has increased. The goal for container plant production operators should be for no irrigation water to leave their property (Yeager et al., 1997). To the maximum extent possible, all irrigation runoff should be recirculated with no discharge to public waters.

A variety of structures, storage facilities, water conveyance and landscape features can be used to direct and manage water movement around nurseries. Several BMPs related to handling and recy- 
cling runoff are the most effective BMPs for reducing environmental impacts. In areas with sandy soils, some nurseries have developed closed systems where drainage channels and collection basins are lined to prevent nitrogen movement from runoff into shallow groundwater.

Information regarding riparian buffers, filter strips, grassed waterways, irrigation tailwater recovery, water conveyance landscape features and other water control structures can be found on the Natural Resources Conservation Service; National Handbook of Conservation Practices website at <http://www.ftw.nrcs.usda. gov/nhcp_2.html> (Natural Resources Conservation Service, 2002).

Grassed waterways are channelshaped or graded areas where vegetation serves as a stable conveyance for runoff. One of the primary functions of a grassed waterway is to reduce the velocity of runoff water. Grassed waterways are frequently located between growing areas or between growing areas and catch basins. These waterways should be designed so water enters and leaves in a sheet flow or so drainage channels contain adequate vegetation to decrease development of erosion channels. The vegetation in the waterway may also serve as a filter, removing some of the sediment contained in runoff. Like filter strips, grassed waterways should not be used as travel lanes.

The most effective BMP for protecting water quality in all watersheds in North Carolina has been identified as maintenance or development of $50 \mathrm{ft}(15 \mathrm{~m})$ riparian buffers along all natural conveyances including streams, rivers and estuaries. City stormwater, new construction, and agricultural operations, are all required to maintain existing buffers. Nurseries frequently have large areas of impervious surfaces that create unique challenges for handling stormwater. Most nurseries are designed to recapture irrigation runoff for recharging irrigation supplies. Therefore nurseries must develop plans for management of stormwater runoff immediately following a rainstorm. Whenever possible, a stormwater management system should take advantage of the contour and topography of a site. Stormwater should be routed over long distances and grading should be developed to reduce water velocity, directing water through grassed waterways, constructed wetlands, vegetative buffers, or other areas designed for overland flow.

The Natural Resources Conservation Service; National Handbook of Conservation Practices Website provides stan- dards for at least three types of irrigation, water and sediment and tailwater structures. A irrigation storage reservoir is a water storage structure made by constructing a dam. For container nurseries a minimum of a 30-d supply of 27,154 gal/acre $\left(102.8 \mathrm{~m}^{3} \cdot \mathrm{ha}^{-1}\right)$ perdayshould be planned. If rainwater is allowed to discharge from the property, this fact must be considered in the design of the retention basin. In planning storage capacities, growers may consider storage of about $90 \%$ of the water applied. A water and sediment control basin is an earth embankment constructed across the a slope and minor watercourse to form a sediment trap and water detention basin. The primary purpose of a water and sediment control basin is to reduce gully erosion and trap sediment. Nurseries frequently use a water and sediment control basin to intercept runoffcoming from beds before it reaches a water supply or irrigation retention structure. Stormwater requirements specify that the basin must be large enough to control the runoff during a 10-year, 24-h-frequency storm without overtopping. An irrigation system, tailwaterrecovery facility isconstructed to collect, store and transport irrigation tailwater (runoff) for reuse in the farm irrigation distribution system. The purpose is toconserveirrigation water supplies for reuse.

Growing beds and drainage channels in sandy soil areas with seasonal or perennial shallow water tables can be lined with plastic or covered with plastic to prevent runoffand nutrientloss to shallow groundwater. In clay soils, impervious bed preparation and lined drainage returns reduces silt and increases the percentage of water returned to capture basins from irrigation events. Concrete or plastic lined waterways or drainage channels reduce erosion adjacent to growing areas but can increase the velocity of runoff water. Where lined sections are not on steep slopes, use of riprap or vegetation in channels can slow water movement, allowing sediment and dissolved substances to settle or be filtered out of returning water. Drainage channels can be established with permanentvegetation such as fescue grass or even aquatic plants. Permanent vegetation in drainage channels slows watervelocity, reduces erosion, and reduces sediment and nutrients in runoff water. Permanent vegetation located at outlets of drainage channels also trap organic material, solids, soil, nutrients and other dissolved pollutants in runoff before the water returns to irrigation supplies. Guidelines for construction of nearly anywater managementstructures, vegeta- tive buffers or landscape features can be found on the Natural Resources Conservation Service; National Handbook of Conservation Practices website at <http:/ /www.ftw.nrcs.usda.gov/nhcp_2.html> (Natural Resources Conservation Service, 2002).

\section{Literature cited}

Eakes, D.J., W.J. Foster, C.H. Gilliam, and J.W. Olive. 1990. Effects of method of application and rate of three slow release fertilizers. Proc. S. Nursery Assn. Res. Conf. 35:47-48.

Fare, D.C., C.H. Gilliam, and G.J. Keever. 1994. Cyclic irrigation reduces container leachate nitrate nitrogen concentration. HortScience 29:1514 1517.

Furuta, Tokuji. 1978. Environmental plant production and marketing. Cox Publ., Arcadia, Calif.

Groves K.M., S.L. Warren, and T.E. Bilderback. 1998a. Irrigation volume, application, and controlled-release fertilizers: I. Effect on plant growth and mineral nutrient content in containerized plant production. J. Environ. Hort. 16(3):176-181.

Groves K.M., S.L. Warren, and T.E. Bilderback. 1998b. Irrigation volume, application, and controlled-release fertilizers: II. Effect on substrate solution nutrient concentration and water efficiency in containerized plant production. J. Environ. Hort. 16(3):182-188.

Lamack, W.F. and A.X. Niemiera. 1993. Application method affects water application efficiency of spraystake-irrigated containers. HortScience 28:625627.

Natural Resources Conservation Service. 2002. National handbook of conservation practices. 21 June 2002. <http://www.ftw.nrcs.usda.gov/ nhcp_2.html>

Tyler, H.H., S.L. Warren, and T.E. Bilderback. 1996a. Cyclic irrigation increases irrigation application efficiency and decreases ammonium losses. J. Environ. Hort. 14(4):194-198.

Tyler, H.H., S.L. Warren, and T.E. Bilderback. 1996b. Reduced leaching fractions improve irrigation use efficiency and nutrient efficacy. J. Environ. Hort. 14(4):199-204.

Warren, S.L., T.E. Bilderback, and H.H. Tyler. 1997. Does method of fertilizer application (surface or incorporation) affect nutrient losses of controlled release fertilizers? Proc. S. Nursery Assn. Res. Conf. 42:141-143.

Wright, R.D. 1986. The pour-through nutrient extraction procedure. HortScience 21:227-229.

Yeager, T.H., D.L. Ingram, and C.A Larsen. 1989. Nitrate nitrogen and potassium release from surfaceapplied and growth medium incorporated Osmocote and Escote. Proc. S. Nursery Assn. Res. Conf. 34:47-48.

Yeager, T., C. Gilliam, T. Bilderback, D. Fare, A. Niemiera, and K. Tilt. 1997. Best management practices: Guide for producing container-grown plants. S. Nursery Assn., Marietta, Ga. 